OPEN ACCESS

Edited by:

Lu-Jun Li,

Chinese Academy of Science, China

Reviewed by:

Xiaodong Gao,

Northwest $A$ and F University, China

Shaoliang Zhang,

Northeast Agricultural University,

China

${ }^{*}$ Correspondence: Bingbing Zhu zhubingbing@snnu.edu.cn

Zhengchao Zhou

zhouzhengchao@126.com

Specialty section:

This article was submitted to Soil Processes,

a section of the journal

Frontiers in Environmental Science

Received: 22 January 2021 Accepted: 14 April 2021

Published: 24 May 2021

Citation:

Zhu B, Zhou Z and Li Z (2021) Soil Erosion and Controls in the Slope-Gully System of the Loess Plateau of China:

A Review.

Front. Environ. Sci. 9:657030. doi: 10.3389/fenvs.2021.657030

\section{Soil Erosion and Controls in the Slope-Gully System of the Loess Plateau of China: A Review}

\author{
Bingbing Zhu ${ }^{1 *}$, Zhengchao Zhou ${ }^{1 *}$ and Zhanbin $L i^{2}$ \\ ${ }^{1}$ School of Geography and Tourism, Shaanxi Normal University, Xi'an, China, ${ }^{2}$ State Key Laboratory Base of Eco-hydraulic \\ Engineering in Area, Xi'an University of Technology, Xi'an, China
}

The Loess Plateau has long been suffering from serious soil erosion of which erosion from the slope-gully system is now dominant. The slope-gully system is characterized with distinctive erosion distribution zones consisting of inner and inter gully areas wherein erosion patterns spatially vary, acting as both sediment source and the dominant sediment and water transport mechanism. In this paper, a substantial body of research is reviewed concentrating on the soil erosion processes and control practices in the slope-gully system. The inner gully area is identified as the main sediment source while runoff and sediment from the inter-gully upland is found to significantly affect down slope erosion processes. Correspondingly, the protective vegetation pattern and coverage should be strategically designed for different erosion zones with an emphasis on the critical vegetation cover and pattern to reduce sediment yield of the whole slope-gully system. Check-dam could change the base level of erosion and reduce the slope length of the gully side, which will further decrease the possibility and magnitude of gravity erosion. We concluded that understanding the erosion processes and implementing erosion practices for the slope-gully system are of importance and require more research efforts that emphasize: 1) the influence of upland runoff on erosion processes at downslope; 2) the relationship between hydraulic characteristics of overland flow and erosion process at a slope-gully system scale; 3) physical mechanisms of different vegetation patterns on the slope-gully erosion process.

Keywords: Loess plateau of China, slope-gully system, soil erosion, vegetation recovery and reconstruction, vegetation pattern

\section{INTRODUCTION}

The Loess Plateau (CLP), located in the northwest of China with an area of $6.4 \times 10^{5} \mathrm{~km}^{2}$, has been experiencing serious soil erosion over a long time with a mean annual erosion rate ranging from 5,000 to $15,000 \mathrm{Mg} \mathrm{km}^{-2} \mathrm{yr}^{-1}$, due to the short heavy storms, easily erodible loess soil, steep slope, low vegetation cover, and inappropriate land use (Fu, 1989). More than 70\% of the CLP, now is gully hill dominant which is attributable to the intense soil erosion and massive human activities over the past years.

The landscape of the watershed is unique with the remarkable Loess shoulder-line (LSL) which is the boundary dividing the complex physiognomy of the plateau into the inter-gully area (BC) and inner-gully area $(\mathrm{AC})$ in the light of the formation and topographic features (Figure 1) (Yan et al., 2014). The area above the LSL (BC) generally has been terraced for being gentle, while the area below the LSL (AC) is usually left as barren with a steep slope greater than $35^{\circ}$ (Figure 2). 


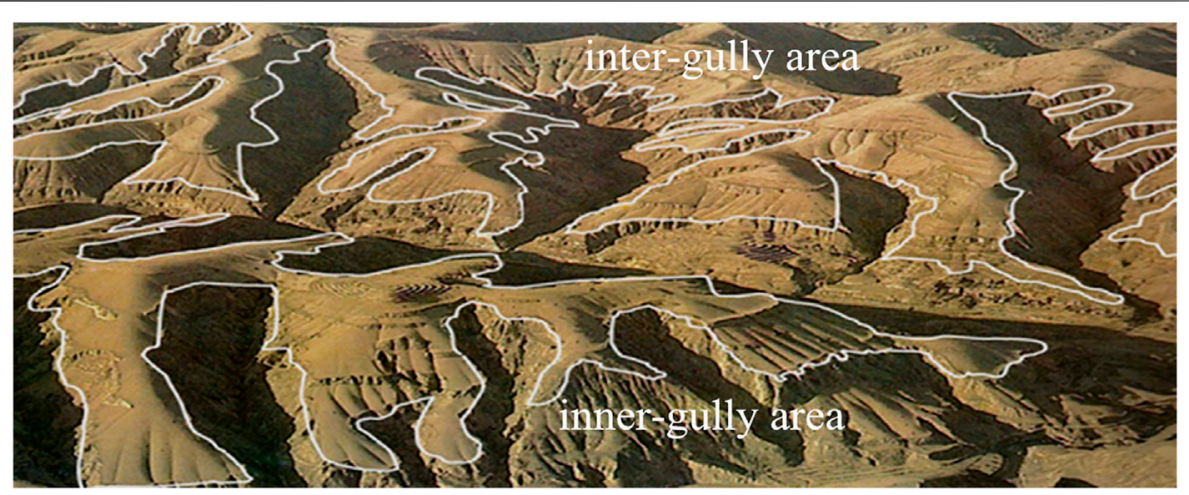

FIGURE 1 | Illustration of loess shoulder-lines on surface (Yan et al., 2014).

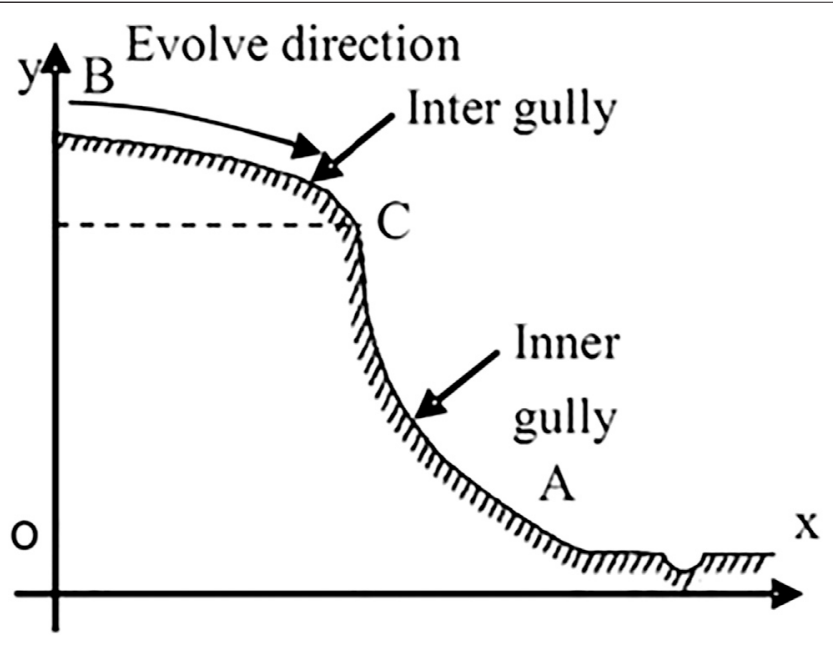

FIGURE 2 | Illustration of loess shoulder-lines profile (Yan et al.,2014).

Erosion patterns in the two areas vary correspondingly, such that, splash, interrill erosion and rill erosion are dominant in $\mathrm{BC}$ while the lower part $(\mathrm{AC})$ is characterized with gravitational erosion or large magnitude landslide. Concerns related with the erosion processes of the two parts were raised from the 1950s with debate on how many sediments they produced and which one is the main sediment source. The answer is vital for decision makers to choose control practices when capital investment is limited. Since then, a lot of studies have been conducted to identify the main sediment source and some consensus has been achieved on certain points: 1) the relative proportions of sediment yield from $\mathrm{BC}$ and $\mathrm{AC}$ spatiotemporally differ; 2) AC is the main sediment source for most circumstances while its sediment yield is significantly affected by the inflow from BC. Inasmuch as their inherent mutual influences, the landform of those two areas combining with different erosion patterns and the related components, such as soil, topography and vegetation, are considered as a special and synthetic system, which is defined as a slope-gully system (SGS) (Lei and Tang, 1997). SGSs can be viewed as a transitional unit from slope to watershed with runoff and sediment connecting the slope with the gully.

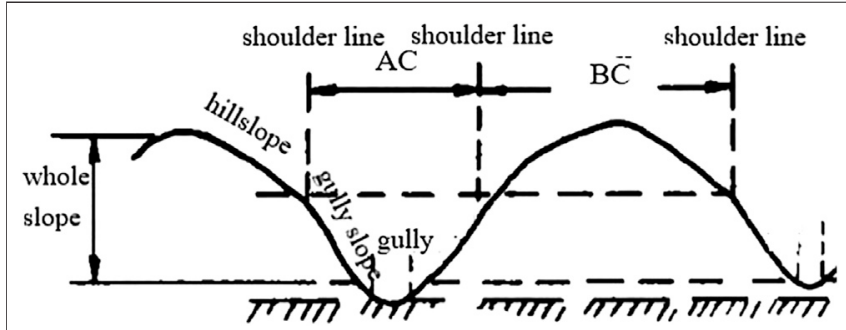

FIGURE 3 | Outline of the loess gullied hilly area.

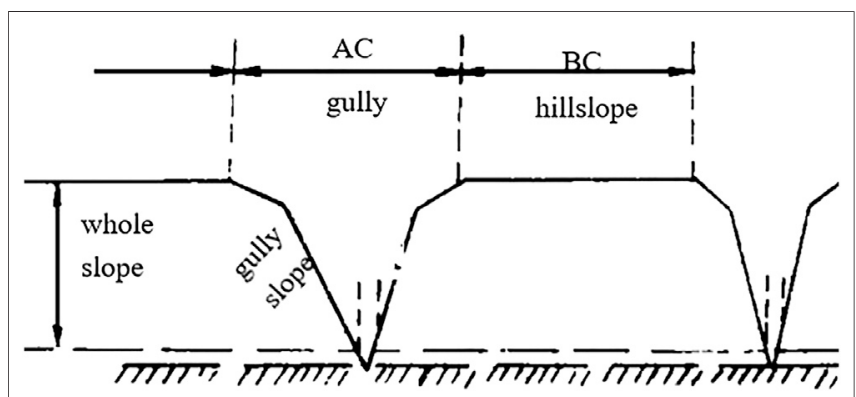

FIGURE 4 | Outline of the loess flat highland area.

SGS is a typical landform in Loess Plateau of China, especially in the loess gullied hilly area and the loess flat highland area. The outlines of the typical watershed in the two areas are exhibited as Figures 3 and 4. The slope profiles of the SGS were both convex with the difference being that the $\mathrm{BC}$ part of the loess flat highland area is almost flat. But for the loess gullied hilly area, the slope gradient increases gradually from $3^{\circ}$ to $12^{\circ}$ at the shoulder, $12^{\circ}-25^{\circ}$ at the upper slope, $18^{\circ}-35^{\circ}$ at the lower slope and $37^{\circ}-42^{\circ}$ at the gully slope (Zheng, 2006). For most circumstances, the upper sections $(\mathrm{BC})$ of these convex slopes are commonly terraced and cultivated but lower down (AC) is found with vertical cliffs or steep slopes.

Correspondingly, erosion control practices should be strategically designed according to the landform and land use 
for the whole SGS. Since the 1980s, a number of biological, engineering, and tillage countermeasures were implemented in the SGS. After more than 40 years of comprehensive management, the total vegetation coverage has gained an increase of 25 28\% (Chen et al., 2015) and more than 100,000 check dams have been built to control gully incision (Xu et al., 2009). The recovered vegetation with variations in vegetation structures, plant diversity and pattern distribution affects both runoff and sediment generation processes. The deposited sediments trapped by the check dam raise the base bed level and reduce slope length, which will further improve the channel stability. The Chinese government now is taking additional effort to build check-dams and 163,300 check dams will be built in the Loess Plateau by 2020 (Xu et al., 2009).

SGS is not only a sediment producing area, but also an important area for implementing ecological reconstructions. Understanding the underlying erosion processes on the SGS in particular under the context of the recovery of vegetation and build-up of checkdam systems will provide more efficient measurements for protecting the limited land resources and ecological environment. Our specific objectives were: 1) to systematically summarize the existing understanding of erosion processes on SGSs; 2) to examine and evaluate the effects of vegetation recovery and checkdam systems on the erosion processes in the SGS scale; 3) to identify prospective research areas on SGSs.

\section{SPATIAL EROSION PATTERNS AND SEDIMENT SOURCES ON SLOPE-GULLY SYSTEM}

\section{Spatial Erosion Patterns of Slope-Gully System}

Understanding the spatial patterns of erosion along a hillslope and the processes of those patterns are of fundamental importance to clarify sediment movement, and are helpful to choose the most effective countermeasures to prevent and control soil erosion. Spatial variations in topography, soil, and land use result in spatial variations in erosion. For the Loess Plateau, the unique topography and its corresponding land use patterns are responsible for the spatial variations in erosion. Owing to the variation of the slope gradient along the slope, water erosion patterns are spatially distributed in such a way that the dominant erosion processes follow the sequence of interrill-rill-ephemeral gully-gravitational erosion-gully erosion-siltation from top to the toe (Chen et al., 1988) and the erosion amount varies from small to large, then becomes small (Cheng, 1965).

For decades, different research groups have carried out intensive work to explain erosion processes in the Loess Plateau with a variety of methods and scales, which was essential to consider effective recuperation technologies (Wei et al., 2012). Systematic conclusions on the vertical erosion zone in the loess gullied hilly area (Table 1) (Liu and Zhu, 1988) and loess flat highland (Liu and $\mathrm{Wu}, 1993$ ) were drawn (Table 2) in the 1990s to illustrate the vertical distributions of different erosion patterns. In general, splash erosion, interrill erosion, rill erosion, and ephemeral gully erosion predominate at the $\mathrm{BC}$ area, while gravitational erosion such as caving, landslide, and subsoil erosion accelerate the development of gullies at the AC part (Liu and Zhu, 1988). This is the basic regularity of soil erosion patterns which are crucial to the effective layouts of soil and water conservation measures.

The study on the spatial erosion patterns of SGS were based on field observations with natural rainfalls, and results were obtained from qualitative methods or combining qualitative with quantitative ones to give a general recognition of erosion characteristics along a complex hillslope of the Loess Plateau (Liu and Zhu, 1988; Chen and Wang, 1999). This type of information was valuable in determining conservation practices and in providing proof for a full understanding of the characteristics of each erosion zone and even soil hydrological behavior, soil erosion mechanisms, and other geomorphologic processes related to soil erosion and sediment yield.

\section{Different Erosion Patterns and Evolution Processes on the Loess SGS}

Different erosion patterns formed an interrelated erosion chain through runoff and sediment along the loess slope. In order to understand the whole erosion chain on the loess SGS, it is of fundamental importance to illuminate the critical conditions for each type of erosion occurring and their evolution processes. Intensive investigations have been conducted to explain the development processes and the influencing factors for interrill erosion, rill erosion and gully erosion with laboratory experiments, field experiments, satellite remote sensing, and digital photogrammetry methods.

Interrill erosion is a process in which a thick layer of water carves the surface into tiny rills and scale-shaped depressions after detaching and taking fine particles in the soil away when the rainfall intensity exceeds soil infiltration. Interrill erosion covers the largest area on the slope of the loess region. It is the first stage of overland erosion with four separated but interrelated subprocesses of detachment by rainfall, detachment by overland flow, transport by rainfall, and transport by overland flow. Focusing on the above four sub-processes and their influencing factors, overland flow hydraulics, and modeling, researchers conducted a number of studies and obtained fruitful achievements over the past 50 years. Zhang and Wang (2017) identified that transport was the process limiting the interrill erosion rate. Wu et al. (2018) pointed out that whether transport or detachment dominate interrill erosion is affected by rainfall intensity and slope gradient in the Chinese loess region and the dominant process changes from transport-limited to detachment-limited when the slope gradients are steep. This result indicated that detachmentlimited process is an important part of the interrill erosion processes. Within the detachment-limited process, soil detachment rate decreased in a power function with the sediment load of sheet flow increasing (Wu et al., 2019a). In addition to rainfall and runoff characteristics, soil properties and surface conditions (vegetation cover, roughness, crust) affect interrill erosion processes (hydraulically, erosional processes and sediment characteristics) as well. Several interrill erosion 
TABLE 1 | Vertical zones of erosion processes in a small catchment of the Loess gullied hilly area.

\begin{tabular}{|c|c|c|}
\hline Zone & Position & Erosion patterns \\
\hline \multirow[t]{3}{*}{ Inter-gully water erosion zone } & Top of Loess Liang and Mao & Splash erosion, sheet erosion \\
\hline & Upper land of Loess Liang and Mao & Rill erosion and ephemeral gully erosion \\
\hline & Lower land of Loess Liang and Mao & Ephemeral gully erosion and gully erosion \\
\hline \multirow[t]{4}{*}{ Inner-gully water erosion zone mixed with gravitational and cave erosion } & Top of inner-gully area & Gully erosion and gravitational erosion \\
\hline & Middle part of inner-gully area & Water erosion, gravitational erosion and suffosion \\
\hline & Lower part of inner-gully area & Water erosion and slumping erosion \\
\hline & Toe of inner-gully area & Sedimentation and scouring \\
\hline
\end{tabular}

TABLE 2 | Characteristics of erosion zone for a profile in the Loess flat highland area.

\begin{tabular}{|c|c|c|c|}
\hline \multicolumn{2}{|r|}{ Erosion zone } & \multicolumn{2}{|l|}{ Erosion features } \\
\hline Zone & Subzone & Erosion patterns & Erosion rates \\
\hline \multirow{3}{*}{$\begin{array}{l}\text { Denudation zone in inter-gully } \\
\text { area }\end{array}$} & Slight erosion zone near divide line & Splash erosion and sheet erosion & Slight erosion \\
\hline & Gully developing zone at the middle slope & Rill erosion and ephemeral erosion & Mild erosion \\
\hline & $\begin{array}{l}\text { Rill erosion and suffosion zone near the margin of the Loess } \\
\text { Yuan }\end{array}$ & Ephemeral erosion, gully erosion and suffosion & $\begin{array}{l}\text { Mild-middle } \\
\text { erosion }\end{array}$ \\
\hline \multirow[t]{2}{*}{ Incised zone in inner-gully area } & $\begin{array}{l}\text { Denudation and gully incised zone below the margins of Loess } \\
\text { Yuan }\end{array}$ & Ephemeral erosion, gully erosion and suffosion & Serious erosion \\
\hline & Strongly incised gravitational zone of gully side & $\begin{array}{l}\text { Ephemeral erosion, gully erosion and gravitational } \\
\text { erosion }\end{array}$ & Severe erosion \\
\hline
\end{tabular}

prediction models were developed with the knowledge on the interrill erosion process and its influencing factors. Zhang and Wang (2017) built a lumped model based on two sediment transport modes, rainfall-driven rolling/creeping and flowdriven rolling/sliding. Wu et al. (2019a) developed a model to predict the soil detachment rate by sheet flow with stream power. However, due to the complexity and the limitation of different experimental conditions, developing a process-based interrill erosion model suitable for the loess slope is greatly necessary for soil erosion control and decision making.

Rill erosion contributes more than $70 \%$ of slope erosion and $50 \%$ of the total erosion on the Loess Plateau of China (Zheng, 1988). The rill erosion process is composed of four phases, downward incision and horizontal development along the side of the rill, local erosion on the escarpment of the rill, collapse of the rill walls, and lateral migrations of the rill (Wang, 1998). Therefore, rill development is a complicated three-dimensional process with constant lengthening, widening, and deepening. For each phase, the dominant process and influencing factors are not the same. It is commonly agreed that soil erodibility and rainfall erosivity have direct impacts on rill erosion. Qin and his colleagues (Qin et al., 2018, Qin et al., 2019) established an automatic monitoring system to study rill erosion development, dominant process, quantifying of rill network evolution and rill morphology. They also developed a frame model on slope erosion including interrill and rill erosion based on WEPP with rainfall factor embedded. However, to date, there is still an ambiguous area around the reasons for the initiation and development of rill erosion and the inherent mechanisms for rill network development due to the complexity and randomness of rills.
Ephemeral gullies (EGs) are small channels eroded and filled alternatively by concentrated overland flow and normal tillage at the same location (Wu et al., 2019a). On the Loess Plateau of China, EGs are estimated to contribute $35 \sim 70 \%$ to the slope erosion mass (He et al., 2004). EGs initiated by the convergence and intersection of rills combined with tillage activity mainly occur at the bottom of tilled-slope. The widely spread EGs are the transitional links between rills and gullies in SGS. With time, the main channel of ephemeral gullies interconnected with the rills on lateral side-slopes and previous interrill areas develop into a fully EG network which can represent the imbricated landform of the Loess Plateau. The formation and development of EGs are closely related with soil characteristics, rainfall and runoff, and topography. A few studies illustrated that both upland and lateral inflow play significant roles in downslope EG erosion. The lower rate of inflow triggered greater sheet and interrill erosion at the channel shoulders and the higher inflow rate strengthened the incision of the main EG channel (Wu T. et al., 2019). Xu et al. (2019) reaffirmed this conclusion that upslope inflow, contributing $62 \sim 78 \%$ and $65 \sim 81 \%$ to total runoff and soil loss, respectively, is important to the growth of the main channel and lateral inflow generates rill networks and provides connectivity of interrill areas for runoff and sediment delivery to the main channel. Besides, inflow sediment concentration influenced the EG erosion downslope. The increase in inflow sediment concentration decreased EG erosion since the detachment rate decreased linearly with the sediment load in the gully flow (Zhang et al., 2014) and a critical value of $120 \mathrm{~g} \mathrm{~L}^{-1}$ of EG erosion was detected (Wu T. et al., 2019). If sediment concentration exceeded this value, the EG erosion would be transferred to sediment deposition instead of detachment. Unit stream power is found to be positively related with the soil detachment rate (Zhang et al., 
2014) and linearly with the sediment transport capacity of EG flows (Gong et al., 2011). EG erosion degrades physical soil quality and reduces corn production. The rotation of filling and tilling of the gully decreases the anti-erosivity of the soil and broadens the EG gully catchment area. As a result, a gully head develops, and the lateral incision is strengthened. EGs are considered as the main sediment source for a watershed to some extent. Practice found that naturally restored grassland significantly increased the erosion resistance and reduced the erosion potential of ephemeral gullies (Wang et al., 2018). However, due to the complexity of EG development and its mechanisms, it is difficult to predict and quantify the EGs.

Rainstorm-induced gravitational erosion frequently occurs on the Loess Plateau, with a crisscrossing gullies landscape and collapsible loess in vertical joints. Rainwater infiltrating the soil decreases the anti-shearing strength of the failure surface, and consequently induces gravitational erosion on the steep slope. The Loess Plateau is severely affected by gravitational erosion such as avalanche, landslide, earth flow, and creep (Liu and Zhu, 1988; Lei and Tang, 1997). For SGSs, a gentle slope at the upper part and a steep slope with gradient larger than $35^{\circ}$ is often the typical geomorphologic feature. Most gravitational erosion occurs at the lower parts of a slope-gully system, that is, the AC part. On one hand, due to frequent incision with concentrated flow from the upper part, the ephemeral gullies in the lower gully slope form independent gullies, which easily collapse after rainstorms. On the other hand, the lower part of AC, acting as flood discharge channel during monsoon season, increases the height of its vertical surface with the scouring of runoff, which will affect its stability and induce landslide or collapse.

Being a stochastic and non-continuous process with the integrated influence of definite hydrologic, geologic, and topographic conditions (Xu et al., 2015), erosion due to gravitational force is hard to predict. Recent studies made efforts to analyze the mechanical stability of the slope-gully as a whole system instead of forecasting the stability of the gully slope and gravitational erosion. Models of gravitational erosion were obtained (Wang et al., 2005) and the fuzzy probability method or finite difference software (FLAC 3D) (Yu et al., 2009) was utilized to quantify the collapse probability. Rainfall simulation experiments on steep slopes found that climate and topography had prominent influences on gravitational erosion (Xu et al., 2015). In general, gravitational erosion often causes large amount of soil loss or even hazards on the Loess Plateau, however, site-specific and real-time measurements are impossible due to its indeterminacy and non-continuity. Therefore, focusing on the gravitational erosion processes, disclosing the interactions with rainfall and topography, identifying areas susceptible to gravity collapse, and formulating control measures will be the highlights of future research.

Recent research focused on the correlations between sheet erosion, rill erosion, and ephemeral gully erosion, with the hydrodynamic parameters using SGS models (Wang et al., 2004; Ding et al., 2008), trying to find the hydrodynamic threshold of each erosion occurrence, which is beneficial to disclose the rule of soil erosion on SGSs and build a processbased erosion model. However, these experiments are conducted on man-made indoor SGS models with rainfall simulation methods, which are different with outdoor environments. Besides, the man-made SGS models are not uniform which limits the outcomes applications. Thus, a uniform SGS model is necessary for future study.

\section{Identification of Sediment Source}

The identification of sediment sources is a fundamental and preliminary work necessary for determining a correct model to understand the behavior of the sediment since it gives the different contribution to the sediments of a watershed (Walling and Collins, 2008) and offers a specific area to spend mitigation efforts (Dutton et al., 2013). In particular, it helps to choose suitable countermeasures for SGSs with spatially varied erosion patterns, that in order to achieve the most effective benefits with limited investment, which in part contributes more to the whole watershed sediment yield, BC or AC, should be fully understood. Most scientists hold the opinion that the erosion rate of $\mathrm{AC}$ is greater than that of BC. As aforementioned, various forms of gravitational erosion, including landslides, slumps, and debris falls, exist on steep slopes in the AC area, while interrill erosion, rill erosion and ephemeral erosion were widespread on hillslopes in the BC area. Surveys indicated that some gully heads advanced several meters after one heavy rain (Gong and Jiang, 1979) in the AC area, which will boost sediment yield.

The pioneering systematic study on sediment sources was performed by Jiang et al. (1966). They analyzed data from a field survey of land use and plot observation and concluded that the erosion rate of the $\mathrm{AC}$ is 1.0-4.0 times greater than that of the $\mathrm{BC}$. However, if the size of each area is taken into account on sediment source, the ratio of sediment yield from the $\mathrm{BC}$ area to that of the AC area varied from 0.8 to 1.8 . Note that earlier studies on sediment sources were based on soil loss amount that was indirectly or qualitatively estimated from experimental plot data. Those plot data may not fully represent the natural reality, and the observation period ranging from 3 to 6 years could not take the long-term effects into consideration.

The relative contribution of sediment from the $\mathrm{AC}$ and $\mathrm{BC}$ areas to the total sediment yield varied across different environmental conditions such as topography, lithology, gully type, soil properties, land use, and climate (Zhang F. et al., 2018). Shi et al. (1996) concluded that sediment sources in a catchment varied across the development of gully system, rather than being constant with the Rare Earth Element method and artificial successive rainfall in a simulated catchment. With the development of a watershed, the gully erosion rate decreased from 86.69 to $38.46 \%$ accordingly with erosion patterns evolving from gully incision at the early stage to headcut erosion. The loess gullied hilly area is in a seriously down-cutting period now (Ma et al., 1993), which means that the dominant erosion process is gully incision and the conclusion that most sediment came from the AC part is probable and reasonable. The results obtained from the ${ }^{137} \mathrm{Cs}$ and ${ }^{210} \mathrm{~Pb}$ tracing method in a watershed of the Loess gullied hilly area also indicated that gully erosion produced the highest proportion of sediment (Li et al., 1997). Zhao et al. (2015) also reported that the gully was the main sediment source accounting for $92.8 \%$ of the total sediment in a small watershed. 
Opposite conclusions were drawn that the $\mathrm{BC}$ is the main sediment source which accounts for $70 \%$ of the total deposited sediment from a small watershed for 1959 1987 (Li, et al., 2008). They attributed the differences to the larger area proportion (58\%) of BC and elevation raise of the erosion basis with dam siltation. However, this explanation may be problematic as no sufficient data were available to support the relationship between the raise of channel base and reduction of gully erosion. Even for the same watershed, the relative proportions of sediment yield from the two parts were different for different study periods or methods (Li et al., 2017).

Despite the discrepancy of the results, a major consensus has been achieved. For the loess highland area, most sediment comes from the AC due to the flat plain of the BC. For the loess gullied hilly area, the dominant factor is the area size. If the areas of those two are almost the same, the AC will yield more sediment for its steep gradient. On condition that the $\mathrm{BC}$ area is larger than the $\mathrm{AC}$, the $\mathrm{BC}$ part is supposed to be the main sediment source.

Sediment source identification has been deeply studied in the CLP since the 1950s with fruitful results. Rare Earth Element and radionuclides such as ${ }^{137} \mathrm{Cs}$ and ${ }^{210} \mathrm{~Pb}$ are widely used as tracers in sediment source identification. Particle size analysis and sedimentation trapped by the check dam are also employed in sediment identification. However, little attention has been paid to the effects of revegetation and land use change on sediment sources. Studies showed that vegetation cover and topography control sediment yield on the CLP (Zhao et al., 2016) which will further change the sediment contribution proportion of the AC and BC. With farmland abandoned and returned to grassland since the late 1990s, the average erosion rate from the $\mathrm{BC}$ gradually decreased and sediment from the AC increased comparatively for Sidizui watershed in gullied hilly area which indicated that the sediment source changed with rehabilitation (Li et al., 2017). For a better understanding of the main sediment source area and variation of CLP with the large-scale implementation of 'Grain for Green' project, obtaining a useful reference for more scientifically sound land use and conservation measures, more information should be acknowledged on runoff dynamics and sediment movement process on the slope-gully system. More field and lab experiments are greatly needed to identify the erosion process and its temporal and spatial variations of the slope-gully system.

\section{INFLUENCE OF UPLAND INFLOW ON DOWN-SLOPE EROSION OF SLOPE-GULLY SYSTEM}

The AC part is the main sediment source as demonstrated above. However, the upcoming inflow from the $\mathrm{BC}$ area contributed a lot and should not be ignored. Up-slope runoff discharging into down-slope caused additional sediment delivery. A few quantitative studies have been performed to probe into the processes and effects on a hillslope scale. Earlier field observation in the Loess Plateau showed that runoff from uplands caused additional soil loss at downslope (Chen, 1992; Jiao et al., 1992; Chen and Wang, 1999) compared to no upslope inflow. Based on the concept of net increment of sediment yield, Chen and Wang (1999) confirmed that runoff accumulating from upslope areas resulted in 1.8 times more sediment increment from down-slope. Later, a number of simulation experiments were carried out on SGS models and a power function relationship with a power index greater than 1 was disclosed (Xiao et al., 2007; Ding et al., 2008), which implies that a slight increment of runoff inflow from the upper part will result in a significant increase in soil loss of the AC area. This increment of soil loss was attributed to an increase in the runoff detachment and transport capacity caused by the increase of inflow rate, and a strengthened runoff scouring force. On the contrary, the downslope erosion will be alleviated greatly if the upland inflow is trapped. Therefore, if the impacts of upland inflow are taken into account in sediment source identification for a slope gully system, a conclusion that most sediment comes from the inter-gully area can be drawn.

However, further study showed that the net sediment from the AC area had a negative relationship with the sediment concentration of the upslope either with linear (Xiao et al., 2007; Ding et al., 2008) or power function (Wang et al., 2004). The variation trends are in accordance with the conceptual model of the effects of sediment concentration in eroding water on erosion processes by Ellison (1947). During the erosive rainfall process, upslope runoff with variable sediment moving downslope affects detachment, deposition, and transport at the downslope segment, especially at the loess hillslope of China. If the upland sediment is trapped, erosion of the downslope will be aggregated with the sediment concentration decreasing. Briefly speaking, the best solution to reduce erosion for a slope-gully system is to trap all runoff and certain amounts of sediments from upland. Theoretically, with the decrease of inflow sediment concentration, there should be a turning point for the sediment concentration of upland runoff (Chen and Wang, 1999) at which the dominant erosion process of downslope will change from detachment to deposition. Nevertheless, there is no general agreement on the quantification of the equilibrium point of the sediment concentration and the effects of upland inflow on downslope erosion for the lack of analytical data.

At the hillslope scale, the increase of downslope sediment yield is affected by rainfall characteristics, topographic conditions, inflow amount, and sediment concentration. With the decrease of sediment concentration in up-slope runoff or increase of rainfall intensity, the additional sediment detachment at the down-slope caused by the upslope runoff was augmented. So far, however, there has been little discussion about how to quantitatively depict upslope runoff effects on downslope erosion processes under different rainfall, runoff, and surface conditions at the slope-gully system scale.

\section{SOIL AND WATER CONSERVATION MEASURES AT THE SLOPE-GULLY SYSTEM SCALE}

In recent years, a series of soil and water conservation measures have been implemented, such as planting and reforestation on the 
slope and building check dams to trap sediment in the gully. Vegetation cover on the Loess Plateau is reported to reach 59.6\% in 2013 from $31.6 \%$ in 1999 (Chen et al., 2015) and around 110 thousand check-dams have been built over the past 50 years (Xu et al., 2009). As a result, the sediment discharge into the Yellow River in 2013 was reduced to 0.2 billion tons with 21 billion $\mathrm{m}^{3}$ of sediments captured (Jiao, et al., 2014).

\section{Effects of Vegetation}

For the Loess Plateau, vegetation other than the slope gradient or slope length was the key factor affecting soil erosion after rehabilitation. Vegetation rehabilitation on the hillslope plays a critical role in reducing water and sediment yield at the $\mathrm{BC}$ area and thus to alleviate the erosion at the $\mathrm{AC}$ area since the incoming upland flow is trapped.

\section{Vegetation Effects on the Runoff Amount From the Inter-gully Area}

Scientists have noticed that vegetation exerts a great impact on reducing and repressing soil erosion in the Loess Plateau from the 1950s. Vegetation affects runoff yield both in vertical structures and horizontal distributions, and the impacts differ from scales. In general, vegetation influences the soil erosion process in the following ways: 1) protecting the soil surface from raindrop splashing; 2) providing additional surface roughness and increasing penetration time; 3) improving soil structure and enhancing the infiltration capacity; 4) spatial distribution (including vegetation structure, compostion, species, and layout with surrounding crops) forming a spatial mosaic and source-sink landscape pattern.

Vegetation on the hillslope is found to be effective in reducing flow velocity and increasing interception and runoff time which thus alleviates downslope erosion. The effects of vegetation coverage on erosion have been widely recognized. In general, the runoff amount decreases with coverage rates as a linear (Greene et al., 1994) or exponential function (Liu, et al., 2018) and there exists a threshold of vegetation cover below which runoff would increase greatly (Jiang et al., 1992; Zhu et al., 2010).

However, the influence of vegetation distribution pattern on the runoff yield is ambiguous. At an SGS scale, vegetation distribution position influences total runoff yield and downslope erosion. A few studies (Li et al., 2005; Ding and Li, 2016) stated that there was no difference in terms of runoff yield with a different vegetation position. Most studies supported the opinion that vegetation located at the middle or lower part exerts better effects on runoff reduction (Feng et al., 2018; Ma et al., 2018) because the vegetation at the lower part exerts a more effective obstacle to the connection of water system (Zhang F. et al., 2018). showed that the optimal position for grass strips in the convex hill-slope was $60 \%$ of the upslope length under a rainfall simulation experiment. But Su et al. (2017) presented that the best runoff reduction effect of vegetation position is $25 \%$ of the upslope length under a scouring experiment.

The effects of vegetation position on runoff yield are different depending on the experiment method, inflow discharge, and vegetation coverage. Based on the previous research, vegetation coverage and position significantly influence runoff yield, yet a quantitatively accurate description is difficult to achieve because of the interactions between vegetation, inflow, and topography are not fully understood. For a natural situation, the interactions are even more complicated, which will be greatly influenced by soil, vegetation, topography, and rainfall characteristics.

\section{Vegetation Effects on Sediment Yield From the Inter-gully Area}

A bunch of research has been conducted on the role of vegetation cover in reducing sediment yield on the Loess Plateau which shows that sediment yield decreases in a linear (Greene et al., 1994) or exponential function (Liu, et al., 2018) with coverage increases in general. Two threshold values of coverage rates exist: 1) the lower threshold, in which vegetation can reduce soil loss effectively only if the coverage exceeds; and 2) the upper threshold, the most effective reduction can be achieved when coverage reaches this number and beyond this number, the increasing of the coverage rate will not reduce soil loss significantly. For the Loess Plateau, the lower and upper threshold is 40 and $60 \% \sim 70 \%$ respectively (Jiang et al., 1992).

The spatial distribution of vegetation cover plays a critical role in reducing water and soil loss at slope scale because it affects runoff and soil erosion processes. Slope with vegetation positioned at the lowest part is observed the least soil loss and this phenomenon is most distinguished under high rainfall intensity. But for a slope-gully system, the sediment detachment capacity in the AC area depends on the sediment concentration in the upslope runoff, which will increase with the decline of sediment concentration. Thus, the vegetation located at the lowest part of the upslope or with higher coverage will cause more sediment loss from the AC area, which is not beneficial to control soil erosion. There should be an optimal slope position and threshold vegetation coverage rate for the lowest sediment yield of the whole slope-gully system.

Several experiments were performed to illustrate the impact of vegetation pattern at hillslope on sediment yield, but different results were drawn. The optimal position for grass strips at convex hillslopes was $60 \%$ of the upslope length (Zhang et al., 2018 b) with $25 \%$ vegetation coverage. Li et al. (2005) and Su et al. (2017) found that total sediment yield is the least when vegetation is located at the lowest part of upslope. Besides, sediment reduction benefits are more remarkable for a smaller discharge inflow which implies that the impact of vegetation at hillslope on erosion control is limited because of the frequent high intensity rainstorms in the Loess Plateau.

Studies related with the impact of vegetation on hydraulic characteristics of overland flow have been carried out and results clarified that vegetation cover and position were able to change overland flow hydraulic characteristics. The coverage is found to be more correlated with hydraulic parameters than the position. The mean velocity was found to decrease with the increased grass cover in a linear trend and be the fastest when located in the upper part (Ding and Li, 2016). While a lower or middle position from the summit along the slope length has the lowest velocity when entering the down slope in a rainfall simulation experiment and caused the lowest sediment yield (Zhang et al., 2018b). With grass coverage increasing, Darcy-Weisbach friction increased and 
overland flow carrying capacity decreased which will cause less sediment yield.

In general, grass cover is more effective in reducing sediment than decreasing runoff. Grass position can change the erosion pattern down slope as it changed the acceleration area of the runoff. Increasing vegetation coverage can reduce runoff and sediment yield significantly, however, excessive vegetation may cause soil dryness and influence soil hydrological status since revegetation on the Loess Plateau is approaching the threshold of the sustainable water resources (Feng et al., 2016). Thus, propriate vegetation position and pattern is more critical to reduce soil and water loss. Vegetation pattern, suitable species selection, and their spatial configuration, should be improved to balance the trade-off between erosion control and soil water consumption. However, as to the most effective vegetation position, it is still under dispute. Revegetated plants at down-slope are more preferable in trapping sediment but will cause more serious soil erosion in the AC area. In previous studies, indoor experiments were conducted with grass strips which were distributed to congregate spatially, while under natural situations, vegetation is often distributed randomly with different species. Several research studies were carried out with different vegetation species and patterns at a slope scale, but the combination with the erosion process on steep downslope makes the erosion process on the slope-gully system more complicated. More experiments should be done to illustrate the vegetation impacts on processes of detachment, transport, and deposition of soil materials by erosive rainfalls and runoff and to further build suitable correlations between soil loss and hydraulic parameters influenced by vegetation patterns.

\section{Effects of Check Dam Systems on Slope-Gully System Erosion}

Many years of soil and water conservation practice has demonstrated that check dams are effective measures to control gully erosion by reducing stream bed slopes, disrupting channel connectivity and shortening gully slope length. In the Yanhe watershed, the annual runoff was reduced by less than $14.3 \%$ due to check dams in gullies and up to $85.5 \%$ of the sediment was retained during the rainy season (Xu et al., 2013).

Several studies were carried out to illustrate the siltation effect of check dams on gravity erosion of the slopegully system using soil mechanic modeling software. On one hand, the uplift of the riverbeds behind check-dams as a result of sediment deposition will submerge the area with a steep gradient and change the surface slope composition which will further decrease the possibility of gravitational erosion because gravitational erosion has significant linear positive correlation with gully slope areas of steeper than $32^{\circ}$ (Zhang et al., 2018c). On the other hand, with the rise of the erosion base level, gully slope length reduced greatly, possibility of gravitational erosion decreased, and the stability of slope-gully system was improved (Yu et al., 2010). For a $15 \mathrm{~m}$-high check dam, the gully slope length will decrease from 40 to $60 \mathrm{~m}$ to $20 \sim 40 \mathrm{~m}$ after siltation which will reduce the possibility of a gully side collapse and gully erosion significantly.
Widely distributed check dams play an important role in gully stabilization and sediment regulation in the Loess Plateau. As estimated, 113,500 check dams have been built by the year 2002 and 21 billion $\mathrm{m}^{3}$ of sediment was intercepted which formed $3,200 \mathrm{~km}^{2}$ fertile farmland (Wang et al., 2014). By the year 2020, 163,000 check dams are planned to be built mainly on tributary channels. Check dam systems brought about complex effects on runoff and sediment yield. Most studies were concentrated on the direct function of sediment retention. However, the indirect effects such as gully stabilization and slope length reduction provided by check dams has not been fully recognized.

\section{KNOWLEDGE GAPS AND PERSPECTIVES}

The Slope-gully system is a unique part of the Loess Plateau. It is not only an important component of watershed but also a basic water and sediment transport unit. Research advances in the slope-gully system erosion processes offer interest and promise for soil erosion modeling for it connects the inter-gully and the inner-gully area with successive flow and sediment transfer. Intensive investigations have been carried out to explain the erosion processes of the slope-gully system. Currently, it is agreed upon that the spatial erosion patterns from the top to the toe slope along a slope-gully system section, and the main sediment source is AC. Runoff rolling down to AC with certain sediment concentration is the main cause to inducing landslide or gravitational erosion which creates large amounts of sediment. The strategy to control erosion occurring in the slope-gully system is to reduce the runoff velocity and maintain a certain amount of sediment within runoff downslope to avoid additional sediment detachment. The soil and water conservation measures at present have direct or indirect influences on the runoff and sediment yield of the slope-gully system by changing either the runoff amount or sediment concentration. Due to the complexity of the slope-gully system, there are a few unclear fields, such as dynamic changes of different erosion types, the relationship between runoff upland and erosion at downslope and whole system, and the optimal vegetation patterns on the hillslope to control soil erosion and reduce soil loss.

(1) The influence of runoff from upslope on erosion processes at downslope should be further considered.

The slope-gully system has complex soil erosion processes. Interrill erosion, rill erosion, gully erosion, and gravitational erosion will be found along a slope-gully section. From theoretical and practical perspectives, to quantitatively illustrate the relationship between erosion at $\mathrm{AC}$ and $\mathrm{BC}$ is often viewed as the consensus of soil and water conservation for the Loess Plateau because it is closely related with the policy for watershed management and layout of the countermeasures. It is of great significance to identify the dominant factors on the erosion process down-slope from upland runoff and sediment, to explain how these factors affect erosion evolution, and responses of these factors to the alteration of upland erosion. Revealing the interaction of runoff and sediment at up-slope and down-slope is 
important for erosion modeling on the slope-gully system and the watershed of the Loess Plateau.

(2) The relationship between hydraulic characteristics of overland flow and the erosion process at the slope-gully system scale should be further understood.

Although a few experiments are performed to determine the relationships between overland flow hydraulic parameters and erosion of slope-gully system both on bare soil plots and grassplots, many other highly complex processes remain obscure. For example, critical hydraulic conditions leading to evolution of different erosion patterns, especially gully initiation and development, temporal and spatial changes of hydraulic parameters, as well as the soil detachment-transportdeposition process, and how vegetation affects these factors should be analyzed in more detailed quantitative information. Besides, vegetation, topography, and rainfall attributes together determine infiltration and overland flow characteristics. With the improvements of experimental technologies, the mixed effects of multiple factors on the slope gully system erosion process should be further probed into and better understood.

(3) The influence of revegetation and its patterns on the processes of SGS should be strengthened.

Recent studies investigating the effects of vegetation on erosion processes are limited by simulating vegetation that partially rested on a convergence pattern and embedded in the topsoil, whereas, the potential effects of vegetation roots embedded in deep soil layers on soil hydrological processes remain largely excluded. In addition, for both spatial and

\section{REFERENCES}

Chen, H., and Wang, K. (1999). A Study on the Slope-Gully Erosion Relationship on Small Basins in the Loess Areas at the Middle Reaches of the Yellow River. Geographical Res. 18 (04), 363-372. (in Chinese).

Chen, Y., Jing, K., and Cai, Q. (1988). Modern Erosion and Management in Loess Plateau. Beijing: Science Press, 161-180.

Chen, Y., Wang, K., Lin, Y., Shi, W., Song, Y., and He, X. (2015). Balancing Green and Grain Trade. Nat. Geosci. 8 (10), 739-741. doi:10.1038/ngeo2544

Chen, H. (1992). The Synthetic Effect of Rainfall Characteristics and Runoff from Upper Slope on Sediment Generation. J. Soil Water Conserv. (02), 17-23. (in Chinese).

Cheng, J. C. (1965). Different Runoff Zone along Slope Land the Proceeding of Chinese Geology. Conference. Beijing: Science Press.

Ding, W., and Li, M. (2016). Effects of Grass Coverage and Distribution Patterns on Erosion and Overland Flow Hydraulic Characteristics. Environ. Earth Sci. 75 (6). doi:10.1007/s12665-016-5329-7

Ding, W., Li, M., and Yao, W. (2008). Simulation of Sediment Yielding in Relation to Slope and Gully. Acta Pedologica Sinica 45 (01), 32-39. (in Chinese).

Dutton, C., Anisfeld, S. C., and Ernstberger, H. (2013). A Novel Sediment Fingerprinting Method Using Filtration: Application to the Mara River, East Africa. J. Soils Sediments 13 (10), 1708-1723. doi:10.1007/s11368-0130725-Z

Ellison, W. D. (1947). Soil Erosion Studies-Partl. Agric. Eng. 28, 145-146.

Feng, X., Fu, B., Piao, S., Wang, S., Ciais, P., Zeng, Z., et al. (2016). Revegetation in China's Loess Plateau Is Approaching Sustainable Water Resource Limits. Nat. Clim. Change 6 (11), 1019-1022. doi:10.1038/nclimate3092 temporal scales, the mechanisms of this process have not been characterized explicitly, in the aspect of structure, species, coverage, and spatial distribution of vegetation. Thus, more research must be conducted on the effects of vegetation located randomly and naturally with different species in deep soils on infiltration, water flow, solute transport, and soil detachment, which should combine advanced technology, such as GIS, REE, and LiDAR, and novel experimental techniques to explore measurements of vegetation distribution patterns and soil movements.

\section{DATA AVAILABILITY STATEMENT}

The original contributions presented in the study are included in the article/Supplementary Material, further inquiries can be directed to the corresponding authors.

\section{AUTHOR CONTRIBUTIONS}

All authors listed have made a substantial, direct, and intellectual contribution to the work and approved it for publication.

\section{FUNDING}

This work was financially supported by the National Natural Science Foundation of China (41601285), Key Technologies Research and Development Program of Shaanxi Province (2021ZDLSF05-02) and Natural Science Basic Research Program of Shaanxi (Program No. 2015JQ4099).

Feng, T., Wei, W., Chen, L., Rodrigo-Comino, J., Die, C., Feng, X., et al. (2018). Assessment of the Impact of Different Vegetation Patterns on Soil Erosion Processes on Semiarid Loess Slopes. Earth Surf. Process. Landforms 43 (9), 1860-1870. doi:10.1002/esp.4361

Fu, B. (1989). Soil Erosion and its Control in the Loess Plateau of China. Soil Use Manag. 5 (2), 76-82. doi:10.1111/j.1475-2743.1989.tb00765.x

Gong, S., and Jiang, D. (1979). Soil Erosion and its Control in Small Watershed of the Loess Plateau. Sci. Sin. 12 (11), 1302-1313. (In Chinese).

Gong, J. G., Jia, Y. W., Zhou, Z. H., Wang, Y., Wang, W. L., and Peng, H. (2011). An Experimental Study on Dynamic Processes of Ephemeral Gully Erosion in Loess Landscapes. Geomorphology 125 (1), 203-213. doi:10.1016/j.geomorph. 2010.09.016

Greene, R., Kinnell, P., and Wood, J. (1994). Role of Plant Cover and Stock Trampling on Runoff and Soil-Erosion from Semi-arid Wooded Rangelands. Soil Res. 32 (5), 953-973. doi:10.1071/sr9940953

He, X., Zhang, X., and Tang, Keli. (2004). Soil Erosion Dynamics on the Chinese Loess Plateau in the Last 10,000 Years. Mountain Res. Dev. 24 (4), 342-347.

Jiang, D., Zhao, C., and Chen, Z. (1966). Preliminary Analysis on the Source of Runoff and Sediment in the Middle Reaches of Yellow River. Acta Geogr. Sinica 32 (01), 20-34. (in Chinese).

Jiang, D., Jiang, Z., and Hou, X. (1992). A Study on Process of Soil and Water Conservation and Disposition Model of its Control Measures in Loess Hilly Regions. J. Soil Water Conserv. 6 (3), 14-17. (In Chinese).

Jiao, J., Liu, Y., and Tang, K. (1992). An Approach to Runoff and Sediment Generation of Gully and Intergully Land in Small Watershed. J. Soil Water Conserv. 6 (02), 24-28. (in Chinese).

Jiao, J., Wang, Z., Zhao, G., Wang, W., and Mu, X. (2014). Changes in Sediment Discharge in a Sediment-Rich Region of the Yellow River from 1955 to 2010: 
Implications for Further Soil Erosion Control. J. Arid Land., 6 (5), 540-549. doi:10.1007/s40333-014-0006-8

Lei, A., and Tang, Keli. (1997). Retrospect and Prospect for Soil Erosion Studies of Ridge-Hill-Gully Slope System. Bull. Soil Water Conserv. 17 (3), 37-42. (in Chinese).

Li, Y., Yang, J., and Zhu, Y. (1997). Using ${ }^{137} \mathrm{Cs}$ and ${ }^{210} \mathrm{~Pb}$ to Access the Sediment Sources in a Dam Reservoir Catchment on the Loess Plateau, China. China Nucl. Sci. Technol. Rep., 1-15.

Li, M., Yao, W., and Chen, J. (2005). Impact of Different Grass Coverages on the Sediment Yield Process in the Slope-Gully System. Acta Geograph. Sin. 60 (5), 725-732.

Li, M., Yang, J., Hou, J., and Shen, Z. (2008). Sediment Deposition Process for a Silt Dam in a Small Watershed in Loess Hilly Region. Transcations of the CSAE 24 (02), 64-69. (in Chinese).

Li, Mian., Yang, Er., Li, Ping., Shen, Z., Bao, H., and Ni, Y. (2017). Identifying Sediment Sources from the Inter-gully Area and Gully Area in a Small Watershed in the Loess Hilly Region of China. Environ. Earth Sci. 76 (22). doi:10.1007/s12665-017-7114-7

Liu, B., and Wu, F. (1993). Gully Erosion and its Development on Loess Plateau. J. Northwest For. Univ. (02), 7-15. (In Chinese).

Liu, Y., and Zhu, X. (1988). A Study on the Vertical Zoning of Soil Erosion in the Loess Plateau. Res. Soil Water Conservation (01), 5-8. (In Chinese).

Liu, J., Gao, G., Wang, S., Jiao, L., Wu, X., and Fu, B. (2018). The Effects of Vegetation on Runoff and Soil Loss: Multidimensional Structure Analysis and Scale Characteristics. J. Geogr. Sci. 28 (1), 59-78. doi:10.1007/s11442-018-1459-z

Ma, X., Lu, Z., and Jin, D. (1993). Evolution and Pissipative Structure in the Drainage-Geomorphic System. Acta Geogr. Sin. 48 (4), 367-376. (In Chinese).

Ma, Y., Li, Z., and Ren, Z. (2018). Effect of Different Positions of Grass Strips on Hydrological Connectivity in Slope-Gully System. Trans. Chin. Soc. Agric. Eng. 34 (8), 170-176. (In Chinese).

Qin, C., Zheng, F., Xu, X., Wu, H., and Shen, H. (2018). A Laboratory Study on Rill Network Development and Morphological Characteristics on Loessial Hillslope. J. Soils Sediments 18 (4), 1679-1690. doi:10.1007/s11368-017-1878-y

Qin, C., Zheng, F., Wilson, G. V., Zhang, X. J., and Xu, X. (2019). Apportioning Contributions of Individual Rill Erosion Processes and Their Interactions on Loessial Hillslopes. Catena 181, 104099. doi:10.1016/j.catena.2019.104099

Shi, Hui., Tian, junliang., and Liu, Puling. (1996). REE Tracer Method for Studies on Sediment Sources for a Small Watershed. Sci. China (Series E) 26 (5), 474-480.

$\mathrm{Su}, \mathrm{Y}$., Peng, L., and Li, Z. (2017). Effects of Slope Vegetation Patterns on Energy Regulation and Water-Sediment Response Relations in Slope-Gully System. J. Soil Water Conserv. 31 (5), 32-39. (In Chinese).

Walling, D. E., and Collins, A. L. (2008). The Catchment Sediment Budget as a Management Tool. Environ. Sci. Pol. 11 (2), 136-143. doi:10.1016/j.envsci.2007.10.004

Wang, W., Lei, A., and Li, Z. (2004). Spatial Distribution of Runoff and Sediment in the Vertical Belts of Soil Erosion Chain in Loess Region of Hilly and Gully. Adv. Water Sci. 15 (01), 24-28. (in Chinese).

Wang, G., Xue, H., and Li, T. (2005). Mechanical Model for Gravitional Erosion in Gully Area. J. Basic Sci. Eng. (04), 335-344. (in Chinese).

Wang, Y., Chen, L., Gao, Y., Wang, S., Lü, Y., and Fu, B. (2014). Carbon Sequestration Function of Check-Dams: A Case Study of the Loess Plateau in China. Ambio 43 (7), 926-931. doi:10.1007/s13280-014-0518-7

Wang, W. X., Wang, W., Kang, H., Guo, M. M., Yang, B., Chen, Z. X., et al. (2018). Effect of Naturally Restored Grassland on the Ephemeral Gully Erosion in the Loess Hilly and Gully Region. Ying Yong Sheng Tai Xue Bao 29 (12), 3891-3899. (In Chinese). doi:10.13287/j.1001-9332.201812.016

Wang, G. (1998). Summary of Rill Erosion Study. Soil Water Conserv. China (8), 23-26. (in Chinese).

Wei, X., Li, Z., and Li, X. (2012). Research Progress on Soil Eroison of Slope-Gully Systems in the Loess Plateau. Sci. Soil Water Conservation 10 (1), 108-113.

Wu, B., Wang, Z., Zhang, Q., and Shen, N. (2018). Distinguishing Transport-Limited and Detachment-Limited Processes of Interrill Erosion on Steep Slopes in the Chinese Loessial Region. Soil Tillage Res. 177, 88-96. doi:10.1016/j.still.2017.12.005

Wu, B., Wang, Z.-l., Zhang, Q.-W., Shen, N., and Liu, J. (2019a). Response of Soil Detachment Rate by Raindrop-Affected Sediment-Laden Sheet Flow to Sediment Load and Hydraulic Parameters within a Detachment-Limited Sheet Erosion System on Steep Slopes on Loess Plateau, China. Soil Tillage Res. 185, 9-16. doi:10.1016/j.still.2018.08.012

Wu, T., Pan, C., Li, C., Luo, M., and Wang, X. (2019b). A Field Investigation on Ephemeral Gully Erosion Processes under Different Upslope Inflow and
Sediment Conditions. J. Hydrol. 572, 517-527. doi:10.1016/j.jhydrol.2019. 03.037

Xiao, P., Zheng, F., and Yao, W. (2007). Study on the Sediment Yield and Coupling Mechanism of Slope-Gully System. J. Sediment Res. (02), 30-35. (in Chinese).

Xu, X. Z., Zhang, H. W., Wang, G. Q., Chen, S. C., and Dang, W. Q. (2009). An Experimental Method to Verify Soil Conservation by Check Dams on the Loess Plateau, China. Environ. Monit. Assess. 159 (1-4), 293-309. doi:10.1007/ s10661-008-0630-x

Xu, Y. D., Fu, B. J., and He, C. S. (2013). Assessing the Hydrological Effect of the Check Dams in the Loess Plateau, China, by Model Simulations. Hydrol. Earth Syst. Sci. 17 (6), 2185-2193. doi:10.5194/hess-17-2185-2013

Xu, X.-Z., Liu, Z.-Y., Xiao, P.-Q., Guo, W.-Z., Zhang, H.-W., Zhao, C., et al. (2015). Gravity Erosion on the Steep Loess Slope: Behavior, Trigger and Sensitivity. Catena 135, 231-239. doi:10.1016/j.catena.2015.08.005

Xu, X., Zheng, F., Wilson, G. V., Zhang, X. J., Qin, C., and He, X. (2019). Quantification of Upslope and Lateral Inflow Impacts on Runoff Discharge and Soil Loss in Ephemeral Gully Systems under Laboratory Conditions. J. Hydrol. 579, 124174. doi:10.1016/j.jhydrol.2019.124174

Yan, S.-j., Tang, G. a., Li, F.-y., and Zhang, L. (2014). Snake Model for the Extraction of Loess Shoulder-Line from DEMs. J. Mt. Sci. 11 (6), 1552-1559. doi:10.1007/s11629-013-2484-0

Yu, G., Li, Zhanbin., Peng, Li., Zhang, X., Zhou, B., and Zhao, H. (2009). Numerical Simulation on Gravitational Erosion of Small Watershed System in Loess Plateau. Transcations of the CSAE 25 (12), 74-79. (in Chinese).

Yu, G., Li, Z., and Zhang, X. (2010). Numerical Simulation of Gravitational Erosion in Slope-Gully System on Loess Plateau. Acta Pedologica Sinica 47 (5), 809-816. (In Chinese).

Zhang, X. C., and Wang, Z. L. (2017). Interrill Soil Erosion Processes on Steep Slopes. J. Hydrol. 548, 652-664. doi:10.1016/j.jhydrol.2017.03.046

Zhang, Q., Dong, Y., Li, F., Zhang, A., and Lei, T. (2014). Quantifying Detachment Rate of Eroding Rill or Ephemeral Gully for WEPP with Flume Experiments. J. Hydrol. 519, 2012-2019. doi:10.1016/j.jhydrol.2014.09.040

Zhang, F., Yang, M., and Zhang, J. (2018a). Beryllium-7 in Vegetation, Soil, Sediment and Runoff on the Northern Loess Plateau. Sci. Total Environ. 626, 842-850. doi:10.1016/j.scitotenv.2018.01.156

Zhang, X., Li, P., Li, Z. B., Yu, G. Q., and Li, C. (2018b). Effects of Precipitation and Different Distributions of Grass Strips on Runoff and Sediment in the Loess Convex Hillslope. Catena 162, 130-140. doi:10.1016/j.catena.2017. 12.002

Zhang, X., Fan, J., Liu, Q., and Xiong, D. (2018c). The Contribution of Gully Erosion to Total Sediment Production in a Small Watershed in Southwest China. Phys. Geogr. 39 (3), 246-263. doi:10.1080/02723646.2017.1356114

Zhao, G., Klik, A., Mu, X., Wang, F., Gao, P., and Sun, W. (2015). Sediment Yield Estimation in a Small Watershed on the Northern Loess Plateau, China. Geomorphology 241, 343-352. doi:10.1016/j.geomorph.2015.04.020

Zhao, J., Vanmaercke, M., Chen, L., and Govers, G. (2016). Vegetation Cover and Topography rather Than Human Disturbance Control Gully Density and Sediment Production on the Chinese Loess Plateau. Geomorphology 274, 92-105. doi:10.1016/j.geomorph.2016.09.022

Zheng, Fenli. (1988). Rill Erosion and its Control in the Slopping Farmland of the Loess Plateau. Memoir Northwest. Inst. Soil Water Conservation Academia Sinica 01, 19-25. (In Chinese).

Zheng, F.-L. (2006). Effect of Vegetation Changes on Soil Erosion on the Loess Plateau. Pedosphere 16 (4), 420-427. doi:10.1016/s1002-0160(06)60071-4

Zhu, B., Li, Z., and Peng, L. (2010). Effect of Grass Coverage on Sediment Yield of Rain on Slope. Acta Pedologica Sinica 47 (3), 401-407. (In Chinese).

Conflict of Interest: The authors declare that the research was conducted in the absence of any commercial or financial relationships that could be construed as a potential conflict of interest.

Copyright $\odot 2021 \mathrm{Zhu}$, Zhou and Li. This is an open-access article distributed under the terms of the Creative Commons Attribution License (CC BY). The use, distribution or reproduction in other forums is permitted, provided the original author(s) and the copyright owner(s) are credited and that the original publication in this journal is cited, in accordance with accepted academic practice. No use, distribution or reproduction is permitted which does not comply with these terms. 